\title{
ESCUCHAR AL IMPUTADO EN EL PROCESO PENAL
}

\section{José Luis Eloy Morales Brand ${ }^{1}$}

Tú eres culpable de un delito; por tanto, es posible que lo seas de otros cientos; esta duda me pesa y quiero cerciorarme con mi criterio de verdad: las leyes te atormentan porque eres reo, porque puedes ser reo, porque quiero que seas reo...

BECCARIA; Tratado de los delitos $y$ de las penas.

\section{Resumen}

En un sistema penal acusatorio, el sujeto procesal acusador tiene la obligación de demostrar la culpabilidad de una persona. Así, la declaración que el imputado emita en el procedimiento penal, es un medio de defensa para contradecir todo argumento o prueba de acusación, pues es su derecho para ser escuchado, o negarse a declarar y no autoincriminarse. Si el acusador tiene la obligación de probar y destruir la presunción de inocencia, no se puede trasladar la carga probatoria al imputado, ni valorar su declaración en perjuicio. Entonces, la declaración del imputado es derecho de defensa, y no de medio de prueba de cargo, que pueda ser calificada como una confesión.

Palabras clave: Sistema Penal Acusatorio, Presunción de inocencia, Defensa, Declaración del imputado, Confesión.

\section{INTRODUCCIÓN}

Al desarrollar el proyecto de investigación PID14-1 "La declaración del imputado en el sistema de justicia penal acusatorio en México", en la Universidad Autónoma de Aguascalientes, se ha obtenido información para exponer que la declaración del imputado en el procedimiento penal acusatorio adversarial, tiene la naturaleza de derecho de defensa, y no de medio de prueba de cargo que pueda ser calificado como una confesión. Calificar a la declaración del imputado como un medio de defensa, disminuirá actuaciones de investigación basadas en obtener confesiones, ya que al no valorarse de esa forma las declaraciones, restringirá el interés de obtener la declaración a toda costa.

\footnotetext{
${ }^{1}$ Maestro en Derecho por la Universidad Autónoma de Aguascalientes. Master en Derechos Humanos por la Universidad de Alcalá, Madrid. Doctorando en Derecho Penal por la Universidad de Sevilla, España. Profesor investigador titular, del Departamento de Derecho de la Universidad Autónoma de Aguascalientes, México, donde realiza actividades de investigación y docencia en las áreas de Derecho Penal, Proceso Penal y Derechos Humanos. Cuenta con más de 50 artículos publicados en revistas, así como más de 20 Libros publicados, entre los que destacan "Procedimiento Penal Acusatorio y Litigación Oral", Rechtikal, México, 2013, y “Derecho Penal, nuevo curso de la Parte General”, UASLP; México, 2015. E-mail: jlemb@hotmail.com vol.08, no. 03, Rio de Janeiro, 2015. pp. 1306-1333 1306
} 
En un sistema penal inquisitivo, los derechos del ser humano se consideran obstáculos para combatir la delincuencia: detener y posteriormente investigar, torturar, obtener pruebas ilícitas, y presumir culpable a una persona, son los mecanismos empleados para lograr una sentencia de condena. El órgano acusador sigue basando su investigación en la obtención de una confesión, para de ahí reunir otras pruebas que puedan ser compatibles con tal versión; mientras que la autoridad judicial, sigue validando actos que logran confesiones, al otorgarles valor probatorio, y permitiendo que el imputado sustituya al investigador público en su función de evidenciar un hecho punible.

La Reforma Constitucional Federal de 18 de junio de 2008 en México, responde a un sistema de justicia penal garantista, es decir, a un modelo criminológico basado en el establecimiento de los principios básicos que son capaces de señalar un camino razonable y humano, para el tratamiento de las conductas sociales desviadas, reduciendo la violencia estatal y tratando de evitar la privada. El Garantismo penal se traduce en la tutela de aquellos valores o derechos fundamentales cuya satisfacción, aún contra los intereses de la mayoría, es el fin justificador de los mecanismos de control social formalizados, entre ellos el Sistema de Justicia Pena (FERRAJOLI, 2011).

Será en este nuevo esquema acusatorio, donde la declaración del imputado adquiera nuevamente su esfera de mecanismo de audiencia en contra de acusaciones, y no una técnica para buscar la aceptación del hecho y su responsabilidad.

\section{SISTEMAS PROCESALES PENALES}

En un sistema inquisitivo establece un procedimiento escrito y secreto; no existe posibilidad de defensa para el autor del hecho; la base del procedimiento es la confesión del hecho y el pecado, por lo que las herramientas más efectivas son el aislamiento, la incomunicación y la tortura; el autor no conocía la acusación; no había igualdad del partes pues los Jueces, que nunca eran vistos, se encargaban de investigar, acusar, procesar, valorar, juzgar, imponer y ejecutar las sanciones. Se traduce en un modelo en el que el juicio es una careta necesaria para imponer una pena, con base a la dinámica de "el fin justifica los medios", pues se permite detener y consignar sin averiguar, en vez de averiguar para consignar y, como última opción, detener, y que la declaración del imputado sea un medio de defensa. Inclusive, la propia autoridad tiene facultades "amplias" para recabar pruebas "en razón de la verdad", perdiendo la imparcialidad.

Mientras tanto, un sistema acusatorio requiere la legitimidad de los medios para llegar al fin, por lo que los derechos humanos y fundamentales son la base de la actuación de las autoridades, en un modelo en el que existe un órgano público encargado de la acusación, distinto a quien Juzga, donde existe igualdad para los sujetos procesales dentro de un juicio público y oral, ante un juez imparcial e independiente, en donde existe la defensa 
adecuada y la participación del afectado en una forma real. Es decir, un modelo en el que se requiere juicio, con garantías procesales, para imponer pena (FERRAJOLI, 2011).

Finalmente, el modelo adversarial es aquel donde el acusador y el acusado se consideran adversarios o partes en conflicto, el cual deberá ser resuelto en el procedimiento penal en función al dinamismo que impregnen a sus actividades: producir la prueba, fortalecer su teoría del caso y debilitar la de su contraparte, y negociar la solución del conflicto (PASTRANA, 2009).

Antes de la reforma Constitucional Federal de 18 de junio de 2008, el Sistema de Justicia Penal en México (ZAMORA, 2010) se integraba por un sector normativo, conformado por las normas sustantivas y adjetivas, que contienen todas y cada una de las disposiciones observadas de manera obligatoria en el Estado, relacionadas con el derecho punitivo; y un sector operativo, que se refiere a las acciones realizadas por los subsistemas de Procuración de Justicia, integrado por el sector Policial que preside el Ministerio Público; el Jurisdiccional dirigido por el Juez, y el de Ejecución de Sanciones o sector Penitenciario que está a cargo de la autoridad ejecutora. La Reforma Penal en México se sustenta en el Principio de Intervención Mínima, lo cual implica que el Sistema de Justicia Penal es la última entre todas las medidas protectoras o de control social que hay que considerar, pues sólo debe intervenir cuando fallen otros medios de solución de los conflictos sociales. Parafraseando a Ferrajoli, si el Sistema de Justicia Penal es la técnica de control social más gravosamente dañosa de todas las intromisiones estatales en la libertad y dignidad del ciudadano, sólo debe intervenir después de que otros medios menos agresivos no tengan éxito para resolver el conflicto. El Sistema de Justicia Penal se convierte en la última ratio o recurso a utilizar, pues debe preferirse ante todo el empleo de medios desprovistos coerción penal, y sólo cuando no sean suficientes estará legitimada la intervención del derecho penal.

También el 10 de junio de 2011 se publicaron reformas constitucionales en materia de protección de Derechos Humanos en México. Lo trascendente de esta reforma es que, tanto la norma Constitucional Federal como los Tratados Internacionales sobre Derechos Humanos, adquieren igual jerarquía de aplicación. En este sentido, la autoridad tendrá la obligación de interpretar y aplicar la norma que beneficie y proteja al derecho, la que lo regule en mejor medida, la que lo amplíe, e inclusive la que lo regule ante omisión Constitucional de protegerlo, gracias a la aplicación del principio pro homine.

Partiendo de esta base, la Reforma Penal tiene dos ejes fundamentales (MORALES, 2010):

1. La reacción penal del Estado debe velar por la protección de los derechos fundamentales de los involucrados en el conflicto, es decir, de la víctima, el imputado y la misma sociedad; por lo cual, para poder afectar esos derechos, deberá analizar si tiene legitimación Constitucional para hacerlo, si no existe otro medio menos lesivo o perjudicial al afectarlos, y buscar una proporcionalidad en los derechos en conflicto; $y$ 
2. Lo anterior siempre aplicando e interpretando la juridicidad para buscar el mayor beneficio posible a los involucrados, y el mínimo perjuicio indispensable.

Este modelo garantista está basado en el reconocimiento y protección de los derechos humanos como derechos fundamentales, a través de las garantías constitucionales, internacionales y legales, y en la interpretación de las normas siempre buscando un equilibrio para tratar de resolver o aminorar lo más posible los conflictos penales.

\section{EL PROCESO PENAL Y LA “BÚSQUEDA DE LA VERDAD”}

El sistema procesal penal inquisitivo maneja la Teoría de la búsqueda de la verdad histórica, que consiste en la labor de reconstrucción de lo sucedido por parte del juzgador. El método es simplemente reconstruir el hecho, a partir de la recopilación de pruebas por cualquier medio.

Por otro lado, en el sistema acusatorio adversarial predomina la teoría de la solución del conflicto de intereses, que parte de que todo delito genera, entre los involucrados, intereses opuestos; es decir, son adversarios, y la legitimidad de los medios es lo que vale para llegar al objetivo de resolver su conflicto. Así, esas partes son las partes las encargadas de exponer, sustentar y convencer de su versión e intereses en el procedimiento penal.

Cualquier Derecho Procesal Penal, legalmente instituido, se enfrenta a la necesidad de armonizar, por un lado, el interés en esa supuesta búsqueda de la verdad y, por otro, el interés del procesado en la salvaguarda de sus derechos individuales (ROXIN, 2000). El procedimiento penal tiene que limitar su finalidad a los derechos fundamentales reconocidos en la Constitución (MUNOZZ, 2007) y otras normatividades.

La búsqueda de la verdad se encuentra ligada a los medios de prueba y, en consecuencia, a la naturaleza de la declaración del imputado. La idea de la verdad histórica, o conocer lo que realmente aconteció, se convirtió en un fin peligroso, pues justifica cualquier medio para obtenerla. Ello convirtió al Juez Instructor y al Ministerio Público, en examinadores inquisitivos del imputado, justificando métodos como la tortura y exhortación para conducirse con verdad, con el fin de conocer esa realidad, negando los intereses del acusado en esa búsqueda. En el modelo acusatorio adversarial, al reconocer al imputado como un sujeto del proceso que tiene un interés que se contrapone a la pretensión punitiva, por lo que puede negarse a brindar elementos de prueba que lo incriminen, nos lleva a hablar de un interés estatal limitado por los derechos fundamentales. En el esquema garantista se invierte la idea de que el fin de la verdad justifica cualquier medio, de modo que es únicamente la naturaleza del medio, lo que garantiza la obtención del fin (FERRAJOLI, 2011).

En este sentido, la verdad buscada en el procedimiento penal debe ser aproximada, lo cual funcionará como garantía de que quien resulte condenado, lo será porque verdaderamente y probadamente es culpable; y de 
que a nadie se le impondrá una pena arbitraria, no sólo porque realmente es inocente, sino porque no se pudo probar, en forma definitiva, que sea verdaderamente culpable (CAFFERATA, 2008).

Así, la declaración del imputado, como uno de sus derechos en el proceso penal, tiene que ver con el dilema de la búsqueda de la verdad; es decir, la forma como el sistema punitivo se enfrenta al acusado, para obtener su declaración, y valorarla en el procedimiento, lo que diferencia a los modelos inquisitivos de los acusatorios o garantistas. El objeto del proceso penal es, entonces, la resolución del conflicto, y la obtención de una aproximación de verdad, sólo y en la medida en que se empleen para ello los medios legalmente reconocidos. Este es el precio que hay que pagar por un proceso penal respetuoso, con todas las garantías y derechos humanos, característicos del Estado Social y Democrático de Derecho (MUÑOZ, 2007).

\section{CONFESIÓN Y DECLARACIÓN DEL IMPUTADO}

Calificar una declaración como confesión, es propio de un sistema procesal penal inquisitivo, donde la búsqueda de la verdad, permite cualquier medio para llegar a ella, y quién mejor para decir la verdad que la persona que es tachada de autor del hecho.

Ahora bien, la confesión no es un medio de prueba, sino una valoración; en la práctica procesal penal, se emiten declaraciones de los imputados, y en el momento procesal correspondiente, la autoridad las valora y califica, según su criterio, como una aceptación de hechos propios en su perjuicio.

La necesidad que el proceso penal tiene del acusado, se ha hecho sentir siempre a través de los esfuerzos dirigidos a obtener su declaración de verdad; pero la cuestión de veracidad, en la mente de quien lo interroga porque lo considera culpable, se identifica, en forma desafortunada, con su confesión (CARNELUTTI, 1999).

\section{¿Qué es la confesión?}

Es toda manifestación espontánea del imputado en un proceso penal, en la que admite su intervención en la comisión del hecho delictuoso. Es el reconocimiento que una persona hace contra sí misma de la verdad de un hecho.

Según García Ramírez (GARCÍA, 2000), una de las declaraciones más relevantes y comprometedoras que puede emitir un imputado, es su confesión. Por medio de ella, el acusado admite ser autor o cómplice del delito. Es una declaración voluntaria, a través de la cual, un imputado manifiesta haber tomado parte, o no, en alguna forma en los hechos de la investigación (COLÍN, 2002)².

\footnotetext{
${ }^{2}$ Colín Sánchez indica que la confesión implica la manifestación de haber tomado o no, parte en el delito. Pero si se entiende que son hechos que le perjudican, no puede decirse que si el acusado niega su participación, se valore como una confesión. Esto nos demuestra como el pensamiento contemporáneo en materia procesal penal de México, sigue sosteniendo que las declaraciones del imputado son un medio de prueba de cargo, y no un ejercicio de su defensa. Por otro lado, Carlos Edwars sostiene que el vol.08, nº.03, Rio de Janeiro, 2015. pp. 1306-1333 1310
} 
En opinión de Marco Antonio Díaz de León (DÍAZ, 1982), la confesión del acusado es un medio para probar; sirve para indagar y conocer los hechos delictivos que se investigan en la causa criminal; es un instrumento para la búsqueda de la verdad, la que, como tal, no sólo deber ser considerada apropiada al fin de alcanzarla, sino que debe ser también empleada correctamente por quien la utiliza, para que pueda desempeñar, sin engaño, su cometido.

De acuerdo a estos conceptos, cuando un imputado ejerce su derecho a declarar para contestar el cargo, corre peligro de que lo que exprese pueda ser valorado como confesión en su contra.

\section{Clases de confesión}

La confesión, arrastrando tendencias inquisitivas, ha sido catalogada (CAFFERATA, 2008) como Judicial, cuando se rinde ante los Jueces; o extra judicial, cuando se produce ante órgano distinto al judicial. También puede ser expresa, en forma oral, clara y directa; pura o simple, cuando se acepta la comisión del delito; en forma espontánea, si el imputado se presenta a emitirla; o provocada, cuando las autoridades la obtienen mediante el interrogatorio.

Así, la declaración de un imputado debe calificarse para saber si se valora o no como confesión; esto implica que debe analizarse en su integridad, para verificar que lo narrado concuerde con el hecho investigado, y pueda ser tomado en cuenta en perjuicio, o en su caso, en beneficio de quien la emite.

\section{Requisitos para que una declaración sea valorada como confesión}

Para que la declaración del imputado, pueda ser valorada como una confesión, debe reunir los siguientes requisitos:

Comprobación previa y plena de los elementos objetivos del delito imputado al declarante; es decir, con pleno conocimiento

Debe entenderse que el acusador ha desplegado una completa y eficiente averiguación de los hechos, para poder catalogar a un sujeto como imputado del delito, y pueda tomársele una declaración que los responda. Si la declaración del imputado es un medio para que se defienda, lo lógico es hacerle conocer las pruebas existentes en su contra para que pueda contradecirlas; pues de lo contrario, la diligencia se limitará a que el acusado responda sobre el delito que se le atribuye, sin existir pruebas que lo evidencien, y no podría ejercer su

fundamento de la confesión del imputado, es que, si bien tiene el derecho de alegar su inocencia "también tiene derecho a admitir que ha cometido el delito"(EDWARS, 1996). 
defensa con eficacia, ya que tendría que reducirse a sostener que no es autor, sin poder destruir la prueba de cargo, porque no existe o la desconoce.

Significa que el sujeto debe gozar de todas las facultades necesarias para emitir sus manifestaciones; es decir, que se le informe previa y detalladamente, el hecho que se le imputa, y las pruebas que obran en su contra; pues de lo contrario no puede confesar nada, sino se encuentra enterado del procedimiento, y los hechos no están previamente demostrados.

\section{Hecha por persona mayor de edad}

Tiene que ver con la capacidad de ser culpable de una persona, para los efectos de la formulación del juicio de reproche al sujeto imputable; pero principalmente para verificar la sinceridad del reconocimiento, causas de su producción y las formalidades de su obtención, puesto que se trata de una declaración contraria al instinto de conservación del que la formula (CAFFERATA, 2008).

En su contra

Es decir, que lo manifestado sea contrario a sus intereses; aquí es donde tiene auge y sustento el argumento de la confesión calificada divisible, que implica, que a pesar de que el imputado declare hechos que le beneficien, puede tomarse en cuenta tan sólo lo que le perjudique, sino demuestra plenamente lo expresado a su favor. Argumento que no comparto, pues he dicho que la declaración del imputado es un medio de defensa; debe analizarse como un todo indivisible, y no se le puede trasladar la carga probatoria con relación a un hecho punible.

Desde el momento que la confesión calificada se compone de una confesión en sentido propio y de una defensa, encontramos el problema de la posibilidad de dividir la declaración en dos partes; una en que se contiene la confesión o admisión de la intervención en el hecho punible; y la otra, en la que se da un motivo de exclusión. Esta división se hace con fines de valoración, para tomar únicamente la parte en que se confiesa autor o partícipe.

Pero no se trata de argumentar que una confesión se divide por que el imputado no demostró los hechos que le favorecen; se trata de argumentar que con las pruebas de la investigación, se acredita el hecho que se le atribuye. En síntesis, siempre que la defensa del acusado, no haya sido destruida por otras pruebas, al calificar el valor de su declaración, no podrá dividirse en su perjuicio. En este sentido, si con base a la declaración del imputado, existe duda sobre la veracidad de la acusación, debe obligarse al acusador a presentar las pruebas que acrediten la imputación, o de lo contrario, la declaración del imputado no debe ser calificada y valorada en su contra, ni siquiera como indicio ${ }^{3}$.

\footnotetext{
${ }^{3}$ En Alemania, la fiscalía interviene tan pronto tiene conocimiento de la sospecha de un delito, con la obligación de investigar las circunstancias que sirven para comprobar los cargos, así como descargos, en contra o a favor del imputado. (GARCIA, 2002 ).
} vol.08, nº.03, Rio de Janeiro, 2015.pp. 1306-1333 1312 
De hecho propio

Es decir, que corresponda a conductas realmente ejecutadas por el declarante.

No debemos perder de vista que hay sujetos que se ven inducidos a mentir, y pueden acusar a personas ajenas al delito, o inclusive, atribuirse un hecho que no cometieron. Así, podemos encontrarnos con una inculpación a terceros, como acto de defensa; o frente a una autoacusación, para encubrir a otra persona ${ }^{4}$. Por supuesto que, una declaración inculpatoria hacia otro, que supone negar la propia culpa, será más dudosa que una declaración inculpatoria que implica también una inculpación propia; pero en ambos casos, si sólo existe esta probanza, junto con alguna otra confesión, no deben ser valoradas como indicios para demostrar la participación de los sujetos, si atendemos a que pueden mentir y apartarse de la realidad; además de que, al atribuir una conducta a otro imputado, no se refiere a hechos propios, por lo que no puede adquirir el carácter de una confesión (BUJOSA, 2003).

Una de las técnicas para inducir declaraciones de los acusados, es que los agentes les hacen creer que los coautores o partícipes, ya han declarado y les atribuyeron toda la responsabilidad ${ }^{5}$; así, cuando alguien confiesa a consecuencia del engaño provocado por los agentes investigadores, y la declaración se usa en contra de otro para decretar su culpabilidad, la sentencia que se pronuncie con base a esa auto incriminación es ilegal, al ser obtenida mediante un medio prohibido; y es razonable que no se debe otorgar confianza a un coimputado, cuando su declaración acusatoria no le reporta ningún beneficio, y más si empeora su situación personal ${ }^{6}$.

\footnotetext{
${ }^{4}$ Según Manzini, la confesión a veces se debe a enfermedad mental o a otro desequilibrio psíquico, fanatismo, espíritu de sacrifico, sugestión, razones de lucro, al intento de desviar las investigaciones de la Justicia para dar forma al verdadero delincuente de ponerse a salvo, al objeto de indicar una coartada para eximirse de una imputación mayor, o de conseguir una sentencia contradictoria para recurrir en revisión, al deseo de librarse de interrogatorios atormentadores, etc. (GONZÁLEZ-SALAS, 2003).

${ }^{5}$ En estos casos se emplea el método de la asociación, que consiste en la posibilidad de despertar ideas en el sospechoso, de tal manera que divulgue pensamientos que pretende ocultar. El empleo de esta técnica sirve tan sólo como auxiliar al interrogar de forma directa a un posible delincuente. (MARTÍNEZ, 1998).

${ }^{6}$ En España, no es bastante la confesión de un supuesto autor para que se le tenga como tal y para que no se dirija el procedimiento contra otras personas, según el artículo 820 de la Ley de Enjuiciamiento Criminal. También, con base a la sentencia del Tribunal Supremo de 29 de julio de 1998, relativa al llamado caso Marey, se ha discutido recientemente sobre el valor de las declaraciones de los coimputados. Se sostiene entonces, que las declaraciones de los coacusados, no son del todo declaraciones, puesto que se efectúan carentes de la obligación de veracidad exigible a los testigos, y deben analizarse con especial cuidado, pues pudieron ser prestadas por alguien guiado por móviles de odio personal, por obediencia a una determinada persona, o pudo rendirse con ánimos de autoexculpación o para obtener beneficios penitenciarios. Así, la declaración de un coimputado carece de consistencia plena, pues a diferencia del testigo, no sólo no tiene la obligación de decir la verdad, sino que puede callar total o parcialmente o incluso mentir, puesto que declarar sin la amenaza de pena que incrimina al falso testimonio, al tener el derecho de no declarar contra si mismo, ni confesarse culpable. (IGARTUA, 1999; JAÉN, 2000). Criterio similar se sostuvo en la Sentencia del Tribunal Constitucional Español, expediente 68/2002, de 21 de marzo de 2002. Recurso de amparo 3147/00. Ponente: Magistrado Dña. Elisa Pérez Vera. http://criminet.ugr.es/recpc
} 
En forma libre, sin coacción o violencia

El derecho a la no incriminación requiere de una libertad sin condicionantes de ningún tipo, lo que implica espontaneidad; que sea libre y con voluntad plena, sin que medie violencia o fuerza que lo obligue a decir algo; lo que, en la práctica no se respeta en la mayoría de las ocasiones, pues la violencia sigue imperante en organismos policíacos, y en sus elementos se mantiene la mentalidad de que la confesión es la prueba por excelencia, por lo que, lejos de buscar otros medios para llegar al verdadero conocimiento de los hechos, emplean toda clase de torturas para provocarla, lesionando la dignidad humana y entorpeciendo la administración de justicia (COLÍN, 2002).

Por lo anterior, se prohíben todos los métodos de interrogatorio que restrinjan la libre actuación voluntaria del procesado y la violación de esta prohibición se sanciona con la imposibilidad de usar en el proceso la declaración obtenida bajo coacción. Algunos de los métodos prohibidos son los malos tratos, el agotamiento, los ataques corporales, el suministro de drogas, la tortura, el engaño, la hipnosis, las coacciones ilegales, el detector de mentiras, la promesa de sentencias ilegales y la alteración de la memoria o capacidad de comprensión (ROXIN, 2000; GÓMEZ, 1985; GARCÍA, 2002).

Un buen número de confesiones, sino es que la mayoría, se obtienen por medios reprobables, como la violencia física o moral aplicada en el imputado, por lo que en este apartado, necesariamente debemos analizar las técnicas de tortura aún empleadas en nuestras sociedades.

\section{¿Qué es la tortura?}

La tortura es todo acto por el cual se inflija, intencionalmente, a una persona, dolores o sufrimientos graves, ya sean físicos o mentales, con el fin de obtener de ella o de un tercero, información o una confesión, de castigarla por un acto que haya cometido, o se sospeche que ha cometido, o de intimidar o coaccionar a esa persona o a otras, o por cualquier razón, basada en cualquier tipo de discriminación, cuando dichos dolores o sufrimientos sean infligidos por un funcionario público u otra persona en el ejercicio de funciones públicas, a instigación suya, o con su consentimiento o aquiescencia?.

La crueldad implica lo violento, o que se complace con los padecimientos ajenos; la inhumanidad se refiere a la barbarie, y lo degradante implica humillación. Por otro lado, la severidad o apremio, es todo tratamiento riguroso que incide sobre el aspecto físico de la persona; y la vejación implica un tratamiento humillante que afecta su aspecto psíquico.

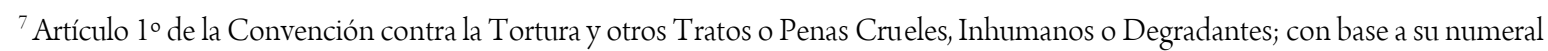
$4^{\circ}$, apartado 1, todo acto que implique la comisión de tormentos, se traduce en un delito.
} vol.08, n. 03, Rio de Janeiro, 2015.pp. 1306-1333 


\section{Elementos de la tortura}

Los elementos de la tortura, pueden ser catalogados en los siguientes (CARRILLO, 2002):

1. Los perpetradores de los actos de tortura:

Son los funcionarios o servidores públicos, u otras personas bajo sus órdenes, que, con motivo de sus atribuciones, infligen dolores y sufrimientos a una persona; por lo regular se da en las áreas policíacas, al detener y mantener la custodia de las personas.

2. Las víctimas de la tortura:

Son los seres humanos que carecen del poder efectivo del Estado; principalmente los catalogados como imputados.

3. Los fines de la tortura:

Obtener de la víctima o de un tercero, una confesión u otra información de utilidad jurídica o política; de castigarla por un acto que cometió o se sospecha que ha cometido, o de intimidarla o coaccionarla, o a persona relacionada con ella, por cualquier razón (COLÍN, 2001).

4. Los métodos de la tortura:

La tortura no ha sido abolida totalmente; si bien ha sido restringida la presión física, la moral subsiste y ha experimentado perfeccionamientos en el transcurso de las últimas décadas (KREMER, 1961).

El hecho de que la tortura haya desaparecido en forma teórica, como medio para obtener pruebas dentro del Sistema de Justicia Penal, no implica que también haya sido eliminada en nuestra realidad social. La presión sobre el imputado continúa siendo el medio del cual se valen los interrogadores para cumplir su función; tienden mediante el interrogatorio, sobre todo cuando se trata de la policía, a debilitar la resistencia del interrogado, de manera que, al final, agotado, no tenga ya fuerza de elegir (CARNELUTTI, 1999).

La tortura puede ejercerse bajo dos tipos de coacción (EDWARS, 1996): la física o psíquica, y la inherente.

Tortura física o psíquica.

Es la que opera sobre el cuerpo o la psiquis del imputado, a fin de obtener su confesión; se manifiesta desde la tortura, los apremios, hasta los interrogatorios capciosos o sugestivos.

1. Coacción física.

Las técnicas más usuales en la tortura física se reflejan en la privación de sueño, alimento y agua; ruido excesivo o extremos de frío y calor; posturas forzadas o incómodas, como el dejar de pie al imputado durante toda la noche y frente a un muro; choques eléctricos; inmersión en agua; golpes en plantas de los pies; introducción de 
agujas debajo de las uñas; asfixias con bolsas; empleo de drogas que producen convulsiones, pérdidas de control corporal, sensación de dolor; no proporcionar el tratamiento médico cuando el imputado haya sufrido daños previos al encarcelamiento policiaco, entre otros.

El sistema represivo echa mano, sin abandonar por cierto las técnicas tradicionales, a nuevas prácticas de tortura que representan una respuesta de adaptación frente a la situación de agitación social. Otro método es el llamado suero de la verdad ${ }^{8}$, donde el sujeto sometido a sus efectos, está sumergido en una especie de sueño hipnótico. Su voluntad queda prácticamente aniquilada; es incapaz del menor esfuerzo, por lo que no puede mentir ni disfrazar la verdad (KREMER, 1961). Por ello es un mecanismo pobre para la investigación, pues sus resultados carecen de valor, debido al estado de indefensión en que se coloca al interrogado, al anularle su voluntad (MARTÍNEZ, 1998).

Estos instrumentos son flexibles para que puedan ser utilizados por personas entrenadas en ellos, en distintos ambientes o lugares, sin dejar huella en la víctima, y dificultan rastrear al torturador y el lugar en donde opera.

\section{Coacción Psicológica}

Existen métodos psicológicos ${ }^{9}$ empleados que hacen invisible a la tortura, y afectan el psique del individuo, creando ansiedad, tensión, pánico y hasta alucinaciones paranoicas, que destruyen la moral del detenido y aniquilan toda su voluntad de resistencia (CARRILLO, 2002; COLÍN, 2001). Los mecanismos psicológicos, regularmente se traducen en un abuso verbal y soez prolongado; amenazas de golpes, violación, o contacto con alimañas; escenificación de ejecuciones; encapucharlo; encarcelamiento solitario; engaños sobre otras declaraciones o atenuantes de sanciones; amenazas de muerte con armas; paseos en vehículos a altas horas de la noche por lugares no conocidos por el imputado; lo sacan de la ciudad, imposibilitándole contacto con su familia o defensor; no dejan que vaya al baño o coma, o descanse, entre otros.

Otra técnica es la de simulación de entrevista con falsos abogados defensores que pretenden sacar información al acusado. También la tortura limpia, donde se afecta sensorialmente al imputado, sin que existan golpes; como lo es la incomunicación. Igualmente se utiliza la manipulación de los medios, pues el torturador emite declaraciones frente a los medios de comunicación, en el sentido de que los detenidos han confesado los hechos que les atribuyen.

\footnotetext{
${ }^{8}$ Descubierto en 1918 por el Dr. House, consiste en una solución de bromohidrato de escopolamina al uno por mil. Este suero se aplica al paciente en dosis de uno a dos centímetros cúbicos, cada media hora, hasta lograr un estado hipnótico, bajo el cual se interroga al sospechoso (SOTELO, 1978).

${ }^{9}$ Por ejemplo, la guía del registro ocular del interrogado, donde el interrogador puede identificar si una persona esta mintiendo, cuando dirige su mirada hacia el lado medio o superior derecho.
} 
Igual técnica de coacción moral es el detector de mentiras ${ }^{10}$; según los que defienden el empleo del polígrafo $^{11}$, si respondes negativamente, cuando sabes que la verdad es otra, el aspecto exterior no traicionará tu falsedad, pero el organismo acusará por una variación de la presión sanguínea, provocada por el estado de alerta despertado en tu interior (KREMER, 1961). Se trata, en sí, de un detector de emociones.

Teóricamente es perfecto; pero en la realidad se crean dudas; ya que el inventor partió del principio de que el aparato está destinado a seres humanos perfectamente equilibrados desde el punto de vista psíquico. Pero es sabido que ciertas personas son emotivas hasta el grado de perder el control en cuanto se les hace la menor pregunta, sin importar las circunstancias. Una de las preguntas que siempre se hace, es la relativa al nivel de exactitud que tienen las entrevistas. ¿Quiénes son inocentes y quiénes culpables? Los inocentes tienen miedo de que el sistema los culpe de algo que no hicieron, y los culpables de que los vayan a descubrir. Quien se somete al polígrafo, más que miedo, tiene ansiedad ante lo desconocido (ROSEN, 2002).

Otro instrumento más innovador para obtener la confesión, es el Psychological Stress Evaluator (MARCEL, 2003), o PSE, que detecta el estrés asociado a respuestas, sin que necesite sensores colocados en el cuerpo del sujeto, ya que graba las preguntas y respuestas, y luego se analizan las gráficas que muestran el estrés vocal al decir o no la verdad.

La coerción moral es bastante amplia, pues incluye cuando el imputado se auto incrimine, frente a la policía o acusador, antes de que conozca del hecho, y sin que se le haya instruido sobre sus derechos; o también que en los inicios de la indagación, se declare a una persona como testigo, y posteriormente ratifique esas manifestaciones, pero en calidad de imputado, a pesar de que en principio se le protestó para que se condujera con verdad, no estaba asesorado de su defensor, y en consecuencia no tenía la libertad de declarar o negarse a hacerlo ${ }^{12}$.

Por lo anterior, se prohíbe la coerción moral, pues hay muchos casos en que se obtiene una confesión del imputado, bajo el temor anticipado a que se afecte su integridad física, sin que haya habido golpes (MARCEL, 2003).

\footnotetext{
${ }^{10}$ No es sorprendente que Lombroso fuera uno de los precursores de este instrumento, pues dentro de sus experimentos científicos, basados en que el delincuente nace y todo ser humano es peligroso, publicó algunos estudios con relación a los cambios de la presión sanguínea, cuando una persona miente (MARCEL, 2003). Fue inventado por el psicólogo norteamericano Dr. Larson, el cual se basó en el complejo de culpabilidad, que hace que cuando una persona miente, sufra una fuerte reacción emotiva, es decir, se tensione (SOTELO, 1978).

${ }^{11}$ Se usa esta denominación por extensión del término, ya que la poligrafía es el arte de escribir diferentes métodos secretos, de modo que lo escrito no sea inteligible, sino para quien pueda descifrarlo (SOTELO, 1978).

${ }^{12} \mathrm{Si}$ se estaba declarando en condición de testigo y se advierte que su condición debe ser la de imputado, se vulnerará el derecho de defensa en estas dos manifestaciones, si no se suspende la declaración y se le advierte de estos derechos y de su nueva condición. Consecuentemente, además, lo declarado previamente no podrá ser utilizado en su contra. (ARMENTA, 2003; BUJOSA, 2003). vol.08, nº.03, Rio de Janeiro, 2015. pp. 1306-1333 1317
} 
Tortura inherente

El segundo tipo de coacción, implica el interrogatorio en sede policial, que resulta coaccionarte por la atmósfera de intimidación que rodea al individuo; pues en un ambiente de este tipo, se destruye la dignidad humana, socavando la libertad hasta impedir una libre elección, por lo que el sujeto termina por sucumbir ${ }^{13}$.

Ante la autoridad, y en presencia de su defensor

La confesión debe ser emitida ante el Juez, y en presencia de su defensor, para que lo asista y verifique que en realidad, el imputado está declarando en forma libre y espontánea; y sobre todo, en ejercicio de su defensa ${ }^{14}$. El imputado no debería rendir declaración ante la Policía o el acusador, sino que todo aquello que quisiera declarar debe hacerse ante la autoridad judicial, pues el procedimiento penal será decidido por el juzgador; y los investigadores, muchas veces buscan obtener la confesión del acusado en la indagatoria.

Que no existan otras pruebas que la hagan inverosímil

Es decir, que lo declarado sea real, concordante y coherente con los demás elementos de prueba que evidencien los hechos punibles; que no sea ilógica, fantasiosa o imposible; en síntesis, que se evidencie claramente que la confesión no ha sido fabricada, sino que está respondiendo sobre los cargos previamente demostrados.

\section{La retractación}

Cuando el imputado se presenta a rendir declaración preparatoria ante el juzgador, por lo regular ya emitió una ante la policía o el acusador, donde confesó la comisión del hecho, por lo que ante el Juez niega lo manifestado, alegando que aceptó la realización del delito, porque se emplearon torturas que doblegaron su voluntad. A esto se le llama retractación, y su finalidad es la de invalidar lo afirmado previamente (COLÍN, 2002); significa que el imputado niega la verdad que contiene su declaración, por variadas razones.

\footnotetext{
${ }^{13}$ La coacción inherente deriva del sistema jurídico de Estados Unidos, según criterio en el caso Miranda vs. Arizona, en donde se estableció que el imputado es arrancado de su ambiente natural, para ser sometido a custodia policial, rodeado de fuerzas antagónicas, permaneciendo incomunicado de su familia y amigos, sin contar con la asistencia y consejo de un defensor, sin que se le dé a conocer previamente su derecho al silencio y sometido a interrogatorio de personas que presentan un celo especial en la represión del delito (GUZMÁN,2000).

14 "En Brasil, la regla es la realización de tal acto sin la presencia de la defensa ... que no deja de ser una visión de clase social. Y es que en el mundo real sólo son interrogados sin abogados aquellos que pertenecen ... a las capas más pobres y marginadas ... jamás los burgueses ... de ahí que más que inquisidores, lo que somos es hipócritas ... La presencia del defensor en el interrogatorio debe ser vista como ayuda personal al propio juez, como un inhibidor de la intolerancia, jamás como un acto menor de desconfianza (BUENO DE CARVALHO, 2003).
} 
Sería lógico que si un acusado alega que confesó el hecho porque fue torturado en sede policial, lo indicado sería analizar minuciosamente el contenido de la declaración, pues es evidente que ello implica una denuncia de un hecho punible que debe ser investigado por la autoridad correspondiente, para verificar la verdad de lo declarado. Pero nuestra respuesta lógica no es la adoptada por la generalidad del Sistema de Justicia Penal Mexicano, en donde se sostiene, que si el imputado alega que sufrió tormentos por elementos policíacos, debe demostrarlo ${ }^{15}$; es decir, que se traslada la carga de la prueba a su persona, para comprobar la comisión de un delito en su contra ${ }^{16}$.

Recientemente, en el año 2013, un Tribunal Federal de Amparo en México ${ }^{17}$, ha establecido dicho criterio, al señalar que no puede otorgarse valor a una confesión de un imputado que alega haber sido torturado para declarar, hasta en tanto no se demuestre la inexistencia de la tortura; lo cual es un gran precedente para desalentar las actuaciones de investigación autoritarias.

Así, el intérprete constitucional traslada la carga probatoria de un supuesto hecho delictuoso, a un sujeto que tiene la calidad de imputado, siendo que, además de ser casi imposible que lo demuestre ${ }^{18}$, pues la tortura se realiza sin testigos y de tal forma que no deje huella apreciable por los sentidos; tal argumento es inadmisible e incompatible con el sistema acusatorio y de carga probatoria que aplica en nuestro sistema constitucional y de justicia penal, que impiden que el imputado pueda asumir el papel de acusador y que tenga la obligación de demostrar un hecho delictuoso.

\footnotetext{
${ }^{15}$ CONFESION COACCIONADA, PRUEBA DE LA. Cuando el confesante no aporta ninguna prueba para justificar su aserto de que fue objeto de violencias por parte de alguno de los órganos del Estado, su declaración es insuficiente para hacer perder a su confesión inicial el requisito de espontaneidad necesaria a su validez legal.

CONFESION ANTE EL MINISTERIO PUBLICO. SUBSISTE SI EN AUTOS NO SE JUSTIFICA LA RETRACTACION. Aun cuando en preparatoria no se ratifique por el imputado su confesión rendida ante el Ministerio Público, la misma debe subsistir cuando en la causa se omita rendir medios de convicción a fin de justificar los argumentos en que se basa la retractación.

${ }^{16}$ Para Rodríguez Manzanera, cuando las conductas abusivas no son presentadas como actos legítimos, tienden a ocultarse, lo que al gobierno se le facilita por el control que generalmente ejercen sobre los medios de difusión, y por la posibilidad de esconder a los directamente responsables, pues no hay quien realice efectivamente la investigación, y de conocerse a los diretos culpables, se les protegerá y no recibirán sanción (RODRÍGUEZ, 2000).

${ }^{17}$ ACTOS DE TORTURA. LA OMISIÓN DEL JUEZ DE INVESTIGAR OFICIOSAMENTE LOS QUE ALEGUEN LOS PROCESADOS, CONSTITUYE UNA VIOLACIÓN A LAS LEYES DEL PROCEDIMIENTO QUE TRASCIENDE AL RESULTADO DEL FALLO, EN TÉRMINOS DEL ARTíCULO 160, FRACCIONES VIII, XIV Y XVII, DE LA LEY DE AMPARO, VIGENTE HASTA EL 2 DE ABRIL DE 2013. 2004374. XXVI.5o.(V Región) 8 P (10a.). Tribunales Colegiados de Circuito. Décima Época. Semanario Judicial de la Federación y su Gaceta. Libro XXIV, Septiembre de 2013, Pág.2434.

${ }^{18}$ Bueno sería saber, cómo pretende un juez, demuestre el indiciado que se le hizo creer que su mujer o su hija eran violadas en la habitación contigua, o que fue golpeado en el estómago y amordazado le echaron agua gaseosa por las fosas nasales, si además la averiguación se acompaña de certificados médicos de no presentar huellas de lesiones, expedidos desde luego por médicos de la misma institución que practicó los interrogatorios; o que estuvo tres días o más encerrado en una habitación oscura sin que se le permitiera sentarse, probar alimentos y hacer sus necesidades, si después de 'confesar' se le permite descansar, comer y asearse, y en el caso de una mujer, cómo se supone pueda demostrar que le aplicaron toques eléctricos en los senos y en sus órganos genitales, si todos estos procedimientos no dejan huella física alguna (ZAMORA, 2000).
} 


\section{LA DECLARACIÓN DEL IMPUTADO: NATURALEZA Y FINES}

En el trato a la declaración del imputado, es donde se aprecian mejor las diferencias entre el sistema inquisitivo y el acusatorio.

Aún existe desacuerdo sobre la naturaleza y fines de la declaración; unos consideran que es un medio de defensa; otros que se trata de un medio de prueba; pero se profundiza poco sobre su razón de ser, independientemente de su forma de valoración en la realidad.

En este sentido, si se le considera como un medio de defensa, implica que se trata de un instrumento que sólo puede utilizarse para la eficacia de la defensa material del acusado; por otro lado, si se le considera un medio de prueba, se convertirá en un instrumento que puede utilizarse para allegarse de elementos de prueba, sin importar que sean de cargo o de acusación, o de descargo o defensa; aunque en la realidad, casi todas las veces se valora en su perjuicio. Así, en virtud de que estas dos finalidades son contradictorias, pues una pretende defender, $y$ la otra aportar pruebas, no puede concluirse que la declaración del imputado es un medio de defensa, y a la vez un medio de prueba de cargo ${ }^{19}$.

En el sistema inquisitivo, el interrogatorio del acusado implicaba el comienzo de la guerra forense, o el primer ataque del fiscal contra el reo (FERRAJOLI, 2011), para obtener la confesión; de ahí el empleo de la tortura y mantener fuera de su alcance los datos que le permitieran conocer el hecho por el que se daba el proceso. El interrogador tenía poderes, y el interrogado sólo deberes: principalmente, el de responder y decir lo que el primero quería oír.

El interrogatorio inquisitivo del imputado, a finales del siglo pasado, se convirtió en la figura de "su libre declaración" (TIJERINO, 2010); es decir, se convirtió en el acto primordial del ejercicio del derecho de su defensa material.

En 1883, el italiano Pessina, ya sostenía en su Sommario di lezioni sul procedimento penale, que el interrogatorio del imputado, no era un medio de prueba, sino de defensa; lo que de igual forma afirmó Manzini, en 1912, donde precisó que el objeto de ese acto procesal, era el de informarle sobre el cargo y hacer efectiva su defensa. Guglielmo Sabatini, apoyado en los autores alemanes, Bennecke-Beling, Binding y Rosenfeid, sostuvo que, en lo penal, el interrogatorio no es un medio de prueba, sino de instrucción y de defensa del imputado orientado al descubrimiento de la verdad. Bettiol, en 1936, opinó que ésta declaración, no debía enfocarse como medio de prueba, sino como una actividad dirigida a solicitar, de parte del imputado, argumentos contra la acusación. Gianturco refirió que una vez que fue abolida la tortura y derogado el régimen de prueba legal, que

\footnotetext{
${ }^{19}$ García Ramírez sostuvo que la declaración preparatoria "es, básicamente, una oportunidad para la defensa del imputado" y "esto nos coloca en el terreno de las declaraciones que puede producir el imputado en el procedimiento, y particularmente la más relevante y comprometedora que es la confesión" (GARCÍA, 2000).
} 
elevaba la confesión a reina de las pruebas, era incuestionable que, en el derecho moderno, la declaración del imputado es una imprescindible formalidad de información sobre la imputación, dirigida a promover su defensa; por lo que le niega el carácter de medio de prueba y le adjudica el de medio de defensa (TIJERINO, 2010).

De acuerdo a lo expresado, considero que la declaración del imputado deriva, en forma inmediata, del principio de defensa o contradicción: la manifestación del imputado, sobre los hechos punibles que se le atribuyen, se traduce en un acto destinado a garantizarle su derecho a ser oído en defensa, frente a la acusación que existe en su contra. Este derecho a declarar sobre los cargos, pretende escuchar al acusado en el ejercicio de su defensa material. El nuevo sistema procesal penal, al facultar al imputado para que rinda una declaración, pretende asegurarle un espacio para que, si lo desea, se manifieste sobre la acusación existente en su contra. Otra cosa será, entonces, las consecuencias que se desprendan del ejercicio de tal derecho, en donde vemos si la misma se valora completamente como un medio de defensa o, por el contrario, si los sujetos procesales la convierten en una trampa para sus intereses, al valorarla como medio de prueba de cargo.

Dentro de una visión inquisitiva, la declaración es un medio de prueba; pero, si reconocemos al imputado su calidad de parte o sujeto procesal, no es congruente sostener que sus declaraciones constituyan medios de prueba de cargo, ya que, por sí mismas, desde el momento que emanan de parte con interés en defenderse, nunca serán idóneas para formar un convencimiento imparcial del juzgador en su contra. Por otro lado, en el sistema garantista acusatorio, que se basa en la presunción de inocencia, el interrogatorio o declaración del imputado, es el principal medio de defensa, y tiene la única finalidad de dar, materialmente, vida al juicio contradictorio, y permitir al imputado, refutar la acusación o aducir argumentos para justificarse (FERRAJOLI, 2011).

Si consideramos a la declaración del imputado como una manifestación o forma del ejercicio de defensa, y no como un medio de probar la imputación en su contra, apareja la consecuencia de una nueva actitud e interpretación al momento de valorar la prueba, y será la única forma de alejarnos de una concepción inquisitiva de búsqueda de la verdad, que justifica cualquier medio, considerando a la confesión como la prueba más eficaz para ello.

En este orden de ideas, la declaración del imputado, se traduce en el ejercicio de su derecho de aportar al proceso, la información que considere conveniente; así que, dentro de su garantía a la presunción de inocencia, se ejerce este derecho de no colaborar con su propia condena, o más concretamente, a decidir si desea voluntariamente introducir alguna información al proceso; por lo que tiene el derecho a declarar, o a negarse a hacerlo. El imputado, luego de ser un medio de prueba, se convierte en sujeto del proceso, con base a su dignidad humana, que prohíbe degradarlo a la calidad de un objeto. Así, al otorgársele la posibilidad de declarar o no 
hacerlo, da pauta a que las finalidades del proceso penal no deben buscarse a cualquier precio, sino que debe aportarse la prueba de la culpabilidad del autor, respetando su dignidad humana.

Con base al esquema triangular del garantismo procesal acusatorio, es decir la existencia de la acusación y la defensa, frente al juzgador que decidirá sobre el hecho, se excluye cualquier colaboración del imputado con la acusación (FERRAJOLI, 2011), puesto que no se puede desplazar sobre él la carga acusatoria de la prueba. No puede considerarse a la declaración del imputado como un medio de prueba de cargo, ya que se traduce en un derecho a no aportar pruebas contra sí mismo, y eso es el límite al poder del Estado, sobre la individualidad del ser humano. Esa protección y respeto del ser humano, es el contrapeso en la aplicación del Derecho Penal, en la supuesta averiguación de la verdad.

Por lo anterior, si afirmamos que el Sistema Penal Acusatorio Adversarial es garantista, hay que considerar a la declaración del acusado como un medio de defensa, y no una prueba de cargo.

\section{DECLARACIÓN DEL IMPUTADO: ALCANCES}

El artículo 20 de la Constitución Federal Mexicana, junto con los numerales 8.2 de la Convención Americana sobre Derechos Humanos, y 14.3 del Pacto Internacional de Derechos Civiles y Políticos, reconocen, por un lado, la existencia de una garantía a la libertad de declarar, y por otro, el derecho del imputado a no incriminarse; siempre frente a la asistencia de una defensa adecuada. La libertad de declarar consiste en que el imputado sea dueño de sus declaraciones, y por ello no puede ser obligado a declarar.

El terror que causó la tortura en tiempos anteriores, provocó, de menos en actos formales, que la mayor parte de los sistemas jurídicos legislaran contra del uso de la violencia para obtener una declaración del acusado; por lo que éstas garantías tienen la finalidad de desterrar esas concepciones inquisitivas que buscaban afanosamente, lograr la confesión del imputado, deteriorando su dignidad (EDWARDS, 1996).

Como la finalidad de la declaración del imputado, es la de permitirle su defensa, está sujeta a reglas que deben respetarse, como el derecho a que se le informe, de manera específica y clara, acerca de los hechos que se le imputan; ser asistido por un defensor desde los actos iniciales de la investigación; practicar actos de investigación para desvirtuar las imputaciones que se le formulen; presentarse ante el Juez, con su abogado defensor, para contestar al cargo; no ser obligado a declarar y, en caso de consentir a prestar declaración, no hacerlo bajo juramento; no ser sometido a tortura u otros tratos crueles, inhumanos o degradantes; derechos que resguardan la persona del imputado, su dignidad, y le respaldan su calidad de parte en la investigación, y no de objeto de ella ${ }^{20}$.

\footnotetext{
20 “Todo el sistema de garantías penales y procesales está dirigido a minimizar el poder del juez, transformándolo en una actividad potencialmente cognitiva ... lo más importante es que la existencia de garantías eleva el grado de limitaciones al juez y facilita la decibilidad de la verdad ... la actuación del juez será legítima cuando haya sido posible conferir a la sentencia la cualidad de haber aprehendido el tipo de verdad que puede ser constatada de modo más o menos controlable por todos, pero esto sólo sucederá si vol.08, nº.03, Rio de Janeiro, 2015.pp. 1306-1333 1322
} 
Si la presunción de inocencia implica el desplazamiento de la carga de la prueba al sujeto procesal acusador (pues quien niega la inocencia, tiene el deber de demostrar la culpabilidad), esto se traduce, de manera lógica y necesaria, en que nunca puede recaer en el imputado, la obligación de declarar o de aportar elementos de prueba que lo lleven a su propia incriminación.

El derecho a no declarar contra sí mismo o confesarse culpable, es expresión de los principios garantistas de presunción de inocencia, acusatorio, carga probatoria y contradicción; por lo que, la declaración de un imputado, es una de las situaciones procesales de mayor importancia, ya que en ese instante se enfrenta al aparato punitivo del Estado, y todo lo que decida o no declarar, debe ser tomado como un acto de autodefensa. El objetivo del establecimiento del derecho a declarar, es el de eliminar toda posibilidad de obligar al acusado a cooperar en la formación de una convicción en su contra, por lo cual se prohíbe el empleo de declaraciones que se hubieran conseguido por medios ilícitos, ya que ha dejado de ser un objeto de prueba, para convertirse en un sujeto procesal. Entonces, podemos afirmar que el derecho fundamental de presunción de inocencia, junto a los de defensa, acusación y carga probatoria, son los que dan origen al derecho a no autoincriminarse; basados en la dignidad de la persona, como fin principal de los sistemas penales que se dicen.

En este orden de ideas, podemos concluir que:

1. La declaración del imputado, esencialmente es un medio para defenderse del cargo o acusación en su contra, sin que pueda ser analizada como prueba de cargo o autoincriminación.

El comunicarle los hechos que se le atribuyen, tienen como objetivo que conozca la acusación que lo incrimina en el hecho punible, para que conteste el cargo si asílo desea(GÓMEZ, 1985; GARCÍA, 2002), y desde el inicio pueda plantear y fortalecer su defensa. Esa comunicación debe ser previa y sin demora; es decir, la comunicación o información del hecho debe efectuarse antes de la realización de cualquier acto procesal en la que intervenga el imputado; y de forma detallada, ya que su contenido debe comprender tanto el relato del hecho atribuido, como los datos de prueba existentes en su contra.

La declaración del imputado es un medio de defensa y no uno de prueba, ya que los elementos incriminatorios tienen que ser procurados por fuera e independientemente de las reservas a que tiene derecho el imputado. Dicho en otros términos, el sujeto acusador debe hablar con los indicios y los demás rastros que toda actividad criminal deja como resultado que espera ser encontrado o revelado (OLIVARES, 1999). Por ello se debe reconocer a quien se encuentra sometido a un proceso penal, su derecho a prestar declaración para exponer lo que le convenga contra la imputación que se le formula, no para perjudicarle.

En este orden de ideas, la declaración del imputado es el principio del ejercicio de su derecho de defensa; no es una diligencia de mera forma, sino un acto primordial para la libertad personal, pues en ella, el acusado podrá (BUENO DE CARVALHO, 2003). 
decir todo aquello que considere necesario en relación al hecho punible que se le imputa, una vez que haya entendido el alcance de la garantía de no autoincriminación.

2. Dentro de su derecho a declarar, el imputado puede abstenerse de hacerlo o guardar silencio; por lo que debe informársele esa situación. Si ejerce su derecho a no declarar, por ello no se puede presumir un indicio de responsabilidad.

El imputado no puede ser obligado a declarar ${ }^{21}$; el derecho de permanecer en silencio, si lo estima conveniente, es una manera de decir que es inocente, y que se pruebe entonces lo contrario. Por este motivo, el silencio del imputado no puede ser tenido como indicio de culpabilidad, y no puede ser valorado por el Juzgador como dato de participación del imputado, al ser la nada fáctica y jurídica; y el ejercicio de un derecho nunca puede significar un perjuicio para quien lo lleva a cabo.

El silencio del imputado, constituye una posible estrategia defensiva, o garantizarle la futura elección de ella, si el Ministerio Público no cumple con sus funciones de demostrar la totalidad del hecho punible. Es uno de los mecanismos principales de protección al derecho de defensa, ya que, por lo regular, cuando una persona entra al Sistema de Justicia Penal, considera que tiene el deber de declarar para justificar su conducta, al creer que no tendrá alguna otra forma de defenderse; por lo cual, es necesario que se le comunique que puede ejercer libremente ese derecho, sin que ello implique una valoración en su contra.

El silencio no puede generar ninguna consecuencia en perjuicio del imputado; no puede ser considerado como indicio de culpabilidad, y no opera la confesión ficta, como en otras materias, donde el callar implica una presunción de certeza de los hechos controvertidos. Esta falta de efecto se relaciona con la carga de la prueba, pues el imputado no debe probar que es inocente; por ende puede callar si quiere, y no colaborar con la investigación, pues, no se le puede pedir que coopere para lograr su propia condena.

Al establecer el artículo 20, apartado B constitucional, que el imputado no podrá ser obligado a declarar, estamos en la presencia del reconocimiento al derecho al silencio o no incriminación. Su negativa a declarar o actuar, no podrá utilizarse para perjudicarlo, pues si así fuera, en lugar de ser reflejo de la defensa, serían formas de inculparse ${ }^{22}$. Es decir, no se puede utilizar como presunción de culpabilidad en su contra, que el imputado se abstenga de declarar, en el libre ejercicio de su defensa. Este derecho al silencio requiere, necesariamente, que se informe al imputado sobre el goce y ejercicio de tal derecho, a fin de que pueda hacerlo valer; obligación de información, que debe realizarse en todas las etapas o actividades en las que se pueda recibir una manifestación del imputado.

\footnotetext{
${ }^{21}$ También en la quinta enmienda de la Constitución de Estados Unidos de Norteamérica.

${ }^{22}$ Igualmente en el sistema jurídico Argentino (CAFFERATA, 2000). También en el Sistema de Justicia Penal Alemán, el imputado es libre de declarar o no sobre el objeto de la causa, lo que implica que de su silencio no puede derivarse ninguna consecuencia desfavorable, pues de lo contrario sería un silencio autoinculpatorio (ROXIN, 2000).
} 
El investigador y cualquier autoridad, tienen la obligación de instruir al imputado, previamente a un interrogatorio, sobre su derecho a no declarar, y estar asistido de su defensor; si se omite este deber, no pueden tomarse en cuenta sus declaraciones.

Estas limitaciones a las actuaciones policíacas, también se observan en el sistema jurídico de Estados Unidos de América, con sustento en los casos Illinois vs. Escobedo ${ }^{23}$, de 1964, y Miranda contra Arizona (GUZMÁN, 2000), de 1966, en las que se sentó el precedente de que no podía hacerse uso de las declaraciones policiales obtenidas sin las salvaguardas de un procedimiento efectivo que aseguren un cabal respeto al derecho a la no incriminación. El caso Miranda reglamentó en forma precisa, el interrogatorio de una persona detenida por la policía, y estableció que estas reglas debían ser observadas por el funcionario encargado de la aplicación de la ley, y que ha comenzado a interrogar a un detenido, o que de algún otro modo ha sufrido un grave atentado a su libertad de acción.

Estas reglas que deben observarse al detener a un imputado (VANDERBOSCH, 1976), respecto de la tarjeta Miranda, se traducen en informarle que tiene el derecho de permanecer en silencio; todo lo que diga puede y será usado en su contra en el tribunal; tiene el derecho de consultar un abogado y de asistirse por el defensor a lo largo del interrogatorio. En resumen, la jurisprudencia estadounidense estableció que el derecho a la no incriminación prevista en la quinta enmienda, comprende los siguientes supuestos: uno implica que un acusado en juicio no puede ser obligado a declarar en su contra; otro supuesto es que tiene derecho a guardar silencio; también en que un testigo de un procedimiento cualquiera, donde legalmente se exija su testimonio, puede negarse a contestar las preguntas cuya respuesta pueda incriminarle en una futura causa o que ponga en evidencia otras pruebas en su contra. De este modo se reconoce en el sistema anglosajón este derecho tanto para el acusado como para el testigo; y, finalmente, que ni el acusado o el testigo pueden ser obligados a exhibir libros o documentos que pudieran incriminarles.

La comunicación de estos derechos, no deben efectuarse en forma amenazante, y deben llevarse a cabo desde el primer momento en que la investigación esté centrada en el imputado; si se le arresta; y, con mayor razón, si se pretende obtener de él una declaración, puesto que la atmósfera de coerción es inherente al lugar de detención donde el sospechoso se encuentra asilado del mundo exterior (QUISPE, 2006).

\footnotetext{
${ }^{23}$ La Suprema Corte de Justicia de los Estados Unidos, resolvió: "Se considera que la investigación de un delito cuando existe un imputado, no es ya la averiguación de un crimen por resolverse, sino que habiéndose enfocado hacia una persona que ha resultado sospechosa de su comisión y que se encuentra detenida, bajo la custodia de la policía, ésta debe llevar a cabo un interrogatorio en el que se eviten y eliminen circunstancias que puedan provocar afirmaciones auto incriminatorias, que sean la consecuencia de haber privado al acusado del derecho de consultar con su abogado, antes de contestar y de que la policía no lo haya impuesto de su derecho a permanecer callado. De conformidad con el artículo sexto de la Constitución de los Estados Unidos, en correlación con el decimocuarto, ninguna confesión obtenida por la policía durante un interrogatorio practicado a un acusado a quien se haya privado de sus derechos constitucionales, puede ser usada en su contra en un juicio de lo criminal" (SOTELO, 1978).
} 
3. Si el imputado decide declarar, no se le debe exigir juramento ni exhortarlo a decir la verdad.

Históricamente, la declaración del imputado se encontró ligada al juramento y a los juicios de dios, pues la confesión era la forma en que purgaba su alma por el hecho cometido. Hoy el juramento se encuentra desterrado de la mayor parte de los ordenamientos jurídicos, pues se ve en él una exigencia y una obligación moral. De igual forma, se prohíbe exhortarlos a que se conduzcan con verdad, pues ello es un reflejo del modelo inquisitivo que se basaba en la búsqueda de la verdad material a cualquier precio. Pero, za qué se debe esta prohibición?; es respuesta a la cuestión ética y sentimental del ser humano, pues exigir un juramento supone un tormento espiritual que condiciona la libertad de declarar. Como señalaba Beccaria, no se puede exigir al reo que diga la verdad cuando tiene el mayor interés en encubrirla: como si el hombre pudiera jurar a contribuir a su propia destrucción (BECCARIA, 1999).

Estas prevenciones se traducen en una coacción a la libertad del imputado, ya que puede ser influenciado en su comportamiento, y estimularlo en un deber de colaboración, para en su caso, inducirlo a confesar.

4. El imputado, tiene el derecho de faltar a la verdad en sus declaraciones.

Como en nuestro Sistema de Justicia Penal no se puede exigir juramento al imputado, para no inducirlo a confesar, no se puede esperar que lo declarado sea verdad y, en consecuencia, no existe responsabilidad por su falsa declaración. La afirmación de que no se puede exigir al imputado que colabore en su propia condena, cobra nuevamente validez para esta situación, una vez que decide declarar, no se puede esperar que se constriñe a la verdad, en el caso de que contenga elementos que lo perjudiquen (QUISPE, 2006).

Cuando un acusado externa su deseo de declarar, no se le puede exigir que rinda protesta de decir verdad, o si falta a ella, no se le puede imputar el delito de falsedad en declaraciones, al no tener la obligación de decir la verdad ${ }^{24}$, pues de lo contrario se le estaría coaccionando para que declare en su contra.

Las falsas declaraciones de un imputado, si bien no pueden constituir ese delito, ante la evidencia de que se trate de una actitud defensiva, tampoco pueden estimarse como un indicio de culpabilidad, ya que la falta de sanción de esa conducta, se debe a que no existe el tercer elemento del delito, que es la Antijuridicidad, por la causa de justificación o autorización del ejercicio directo de su derecho de defensa, que tiende a controlar el modo en que se pretende probar su culpabilidad, y no la de garantizar la oportunidad de probar su inocencia ${ }^{25}$, al ser éste su estatus jurídico durante todo el procedimiento.

5. El imputado puede declarar cuantas veces lo considere necesario, pero solo a petición directa.

\footnotetext{
${ }^{24}$ En el sistema jurídico de España, también se otorga este derecho a faltar a la verdad (JAEN, 2002). Por el contrario, en el sistema Estadounidense, iniciada la persecución penal, el Juez explica el hecho y pregunta al imputado si se declara culpable o no culpable, sin poder dar alguna explicación. Durante el juicio, el imputado puede decidir si declara o no lo hace; si decide producir prueba, puede declarar, pero lo hará bajo juramento, pues es considerado otro testigo más, porque libremente decide declarar, sin que nadie lo llame (BOVINO, 1998).

${ }^{25}$ Esta garantía también se observa en el sistema jurídico Argentino (CAFFERATA, 2000). 
En virtud de que el imputado goza del derecho a declarar y a ser escuchado en defensa, puede hacerlo cada vez que considere que tiene algo que expresar sobre el proceso, sólo a petición directa, pues se trata de un derecho personal, y nadie más que por sí mismo puede ser llamado a declarar.

6. Es necesario que esté presente su defensor siempre que emita una declaración en calidad de imputado.

El derecho a ser informado se encuentra íntimamente ligado con el derecho a ser asistido por un abogado defensor, al ser evidente que para muchos acusados, el derecho de hacer o no declaraciones, y el derecho a disculparse, serán puramente teóricos si en el momento de ser informado de esto, no tienen la posibilidad de llamar a un defensor. Lo cual implica que al mismo tiempo de ser informados de su derecho a guardar silencio, también se les debe indicar que deben contar con la asistencia de un abogado defensor ${ }^{26}$.

7. No debe utilizarse medio violento para obligarlo a declarar al imputado o que pretendan viciar su voluntad.

No puede ejercerse ningún tipo de coacción en contra del imputado, ya sea físico o mental, que menoscabe su capacidad de decisión, para tratar de inducir una declaración.

El derecho a la no incriminación requiere de una libertad sin condicionantes, lo que implica espontaneidad. Si el imputado quiere declarar, debe tratarse de una decisión libre y con voluntad plena, sin que medie violencia o fuerza que lo obligue a decir algo. Por lo anterior, se prohíben todos los métodos de interrogatorio que restrinjan la libre actuación voluntaria del procesado y la violación de esta prohibición se sanciona con la imposibilidad de usar en el proceso la declaración obtenida bajo coacción. Algunos de los métodos prohibidos son los malos tratos, el agotamiento, la incomunicación, la atmósfera de intimidación de los centros de detención policiacos, los ataques corporales, el suministro de drogas, la tortura, el engaño, la hipnosis, las coacciones ilegales, el detector de mentiras, la promesa de sentencias ilegales y la alteración de la memoria o capacidad de comprensión.

\section{REFLEXIÓN FINAL}

El Sistema de Justicia Penal formaliza el control social a través de la protección de los derechos humanos de todos los involucrados; es decir, la formalización implica transparencia y claridad del sistema, así como la existencia de principios valorativos que deben observarse en su aplicación (HASSEMER, 1999). En virtud de que existen varios sistemas o mecanismos que pretenden reaccionar contra las desviaciones sociales, y algunos se

\footnotetext{
${ }^{26}$ Amilton Bueno de Carvalho sostiene que “iel acto del interrogatorio, sea medio de defensa, sea medio de prueba, siendo de vital importancia, sólo puede ser afrontado con las garantías constitucionales de amplia defensa y de contradicción, preservadas mediante la presencia atenta del defensor-abogado: garantía del ciudadano frente a la posibilidad de arbitrio del Estado!" (BUENO DE CARVALHO, 2003).
} 
insertan en la estructura del Estado, consecuentemente, será la forma o clase de Estado la que condicione las prácticas de la Política Criminal (BERGALLI, 1983; MIR PUIG, 2006); y en un Estado Constitucional de Derecho, esos mecanismos se ven sustentados en la protección de los Derechos Fundamentales de las personas a las que va dirigido, al someterse a normas de actuación diseñadas para asegurar la objetividad de la intervención y el respeto de los individuos involucrados en el conflicto (GARCÍA-PABLOS, 2008).

Una verdadera Política Criminal democrática, que tenga como límites los Derechos Humanos y Fundamentales de las personas, será aquella que construya un mecanismo de control social penal que tienda a la protección de los seres humanos, afectándolos lo menos posible. Así, en un modelo acusatorio garantista, el desplazamiento de la carga de la prueba sobre la acusación, implica en forma lógica, el derecho de defensa para el imputado.

El principio de defensa se traduce en la necesidad de enfrentar la acusación en igualdad de condiciones y con posibilidad de conocer y contradecir toda prueba de imputación. Todavía más importante que la necesidad de la prueba, es la garantía del contradictorio, o la posibilidad de la refutación (FERRAJOLI, 2011). La defensa es el poder refutar la hipótesis acusatoria, de modo que no puede tomarse en cuenta ninguna prueba de cargo, sino ha sido otorgada debidamente la posibilidad de su contradicción; es uno de los instrumentos más importantes de control del método de prueba acusatorio (FERRAJOLI, 2011), pues la contradicción implica, más que presentar pruebas en contra, la vigilancia de la realización y respeto efectivo de la presunción de inocencia del imputado.

La contradicción, más que presentar simplemente pruebas en contra de la acusación, se refleja en la vigilancia de la realización y respeto efectivo de la presunción de inocencia del imputado. Si la jurisdicción es la actividad necesaria para obtener la prueba de que una persona ha cometido un delito, hasta que esa prueba no se recabe y valore mediante un juicio legal, ningún delito puede considerarse cometido, y ningún sujeto puede ser considerado culpable ni sometido a una pena. En este sentido, se respeta la presunción de inocencia si se hacen efectivas todas las garantías procesales que el legislador estableció en cada una de las fases del procedimiento, según los actos de que se trate; al implicar el derecho del imputado de recibir el trato de no autor o partícipe de un hecho delictivo, hasta en tanto no se demuestre su culpabilidad.

Este principio Constitucional implica que, al tener el acusador la carga probatoria, es necesario que se lleve a cabo un juicio, en el cual se demuestre que el imputado cometió un delito; por tanto, mientras no exista esa sentencia inapelable, será inocente.

Por otro lado, México forma parte de la Declaración Universal de Derechos Humanos, y del Pacto Internacional de Derechos Civiles y Políticos, aprobados por la Asamblea General de las Naciones Unidas; la Convención Americana sobre Derechos Humanos; el Conjunto de Principios para la Protección de todas las personas sometidas a cualquier forma de Detención o Prisión, de la Asamblea General, mediante resolución 
43/173, que establecen que toda persona es inocente, mientras no se pruebe su culpabilidad. Así, la presunción de inocencia se convierte en una garantía de la libertad personal, tanto contra la arbitrariedad de los poderes públicos, como contra la reacción vindicativa de la víctima, garantía que debe beneficiar a cualquier delincuente, sea primario o reincidente. Puesto que toda persona se presume inocente, cualesquiera que sean las sospechas o los cargos que sobre ella recaigan, debe ser considerada y tratada como tal, en tanto su culpabilidad no haya sido aprobada y declarada mediante una sentencia regular y definitiva (CÁRDENAS, 2006).

La culpa, y no la inocencia, debe ser demostrada; y es la prueba de la culpa, y no la de la inocencia que se presume desde un principio, la que forma el objeto del juicio (FERRAJOLI, 2011). La presunción de inocencia no es sólo una garantía de libertad y de verdad, sino también de seguridad o defensa social, al implicar una función simbólica, ofertada por el estado de derecho, que otorga una confianza de los ciudadanos en la justicia, como un medio de defensa frente al arbitrio punitivo.

El imputado no está obligado a probar que es inocente, sino que es el sujeto acusador, a quien le incumbe la carga de la prueba de los elementos constitutivos del delito y la culpabilidad del responsable; así, el acusado no puede ser obligado a confesar en su contra, por lo que las legislaciones afectan de nulidad todas aquellas confesiones obtenidas por medios ilícitos. Hasta la existencia de la sentencia ejecutoriada de condena, se afirmará que la presunción ha desaparecido, y que tenemos a un culpable, al que se podrá privar de sus derechos, en los términos de la decisión jurisdiccional (ZAMORA, 2000).

La presunción de inocencia dentro del proceso penal, tiene relación con el principio garantista de verificación o carga probatoria, ya que por el carácter público y el interés común que detenta el Derecho Penal, es al Estado, concretamente al sujeto procesal acusador, sobre quien recae la carga probatoria tendiente a demostrar la existencia del delito, la responsabilidad penal del imputado, y el correspondiente reproche de culpabilidad; pues éste, no tiene la obligación de probar su inocencia, dado que goza de una situación jurídica que no necesita ser construida, sino todo lo contrario, ella debe ser destruida por el acusador, para que la presunción de inocencia se desvanezca. De igual forma, el deber del Ministerio Público no se traduce en verificar o comprobar, a toda costa, un hecho punible; sino que tiene la obligación de investigar la verdad objetiva del hecho, independientemente de que ella perjudique o beneficie al indiciado. Esta es una consecuencia de la presunción de inocencia, ya que no es el imputado quien debe probar, sino el acusador, y sólo hasta que logre demostrar la conducta delictiva, la presunción de inocencia podrá desvirtuarse.

En consecuencia, no basta que el órgano jurisdiccional reciba una mínima actividad probatoria; es decir, que se hayan practicado pruebas y que el representante social haya desplegado el máximo celo en investigar el hecho punible y atribuírselo a su autor; sino que es necesario que el resultado de la actividad investigadora pueda ser considerada, en forma racional, como un dato pleno incriminatorio o de cargo, y no de descargo. La 
presunción de inocencia desplaza la carga probatoria al sujeto procesal acusador, a quien corresponde demostrar los elementos de la pretensión acusatoria; en consecuencia, corresponde a la acusación, y no a la defensa, la realización de la actividad probatoria de cargo, necesaria para desvirtuar esa presunción (CARDENAS, 2006).

Por lo anterior, el principio de contradicción o defensa, como vigilante de la presunción de inocencia y garante de los derechos del imputado, en el procedimiento penal acusatorio se refleja en la libertad de comunicación; es decir, el imputado puede comunicarse libremente en el momento que lo requiera, por lo que su declaración es un medio para defenderse de la acusación, no una prueba de cargo; tiene derecho a guardar silencio y a que no se le exija juramento ni exhortarlo a decir la verdad; siendo necesario que esté presente su defensor siempre que emita una declaración en calidad de imputado, independientemente de la autoridad ante la cual se realice. Tiene derecho a no someterse a intervenciones corporales; así mismo, no debe utilizarse ningún medio violento para obligar a declarar al imputado; por lo que está prohibida cualquier forma de manipular su conciencia, como la incomunicación, la amenaza, la promesa o la tortura.

Es así como podemos observar claramente, que la defensa es una facultad sustantiva y fundamental del imputado, y no meramente adjetiva o procesal, ya que se traduce en un derecho que corresponde universalmente a todo ser humano en cuanto dotado del status de persona, de ciudadano o sujeto con capacidad de obrar; es decir, es una atribución que forma parte de su dignidad para su realización integral; la defensa es una expectativa adscrita a un sujeto por una norma jurídica, y su status es la condición como presupuesto de su idoneidad para ser titular de situaciones jurídicas y autor de los eventos que se deriven del ejercicio de éstas; facultad derivada de la norma en que se reconoce ese derecho que puede hacerse valer frente al Estado, para que la garantice mediante la obligación y prohibiciones relativas a restringir de manera indebida el goce de sus derechos fundamentales, y si llega a violarlos, genera otra obligación de sanción o anulación de tales vulneraciones.

La defensa se ejerce a través de la declaración del imputado, pues es el mecanismo que tiene para contestar el cargo, y refutar la acusación en su contra; no es un medio de prueba de cargo, ni una forma de trasladarle la carga probatoria y validar su autoincriminación.

Se trata entonces, de una búsqueda de seguridad jurídica de la persona, al saber que en caso de que se le impute la comisión de un delito, el Estado observará todos y cada uno de los requisitos y elementos previos, tendientes a generarle una afectación válida en su esfera jurídica; es decir, tendrá la certeza de que será acusado por un órgano distinto aquel que deberá juzgarlo, una vez que haya sido oído en el proceso, representado por un defensor, y haya aportado los medios de prueba que permitan fortalecer su inocencia, sabiendo que puede declarar libremente, ya que su dicho no podrá ser utilizado en su contra. 


\title{
LISTENING TO THE ACCUSED IN CRIMINAL PROCEEDINGS
}

\begin{abstract}
In an adversarial system, the accuser to the proceedings has the burden of proving the culpability of a person. Thus, the statement issued by the accused in criminal proceedings, is a defense to counter any argument or proof of accusation, as is their right to be heard, or refuse to testify and self-incrimination. If the prosecutor has an obligation to try and rebut the presumption of innocence, you can not transfer the burden of proof to the accused, or assess their detriment statement. Then the statement of the accused's right of defense, and not a means of incriminating evidence that can be described as a confession.
\end{abstract}

Keywords: Criminal Adversarial System, presumption of innocence, defense, statement of the accused, confession.

\section{REFERENCIAS BIBLIOGRÁFICAS}

ARMENTA, Teresa. Los sistemas de enjuiciamiento penal y sus órganos de acusación; Revista Criminalia; México, N. 2, may/ago, 2003.

BECCARIA, Cesar. Tratado de los delitos y de las penas. 9 ed. Editorial Porrúa; México, 1999.

BERGALLI, Roberto. La instancia judicial, en El pensamiento criminológico. 1 ed. Editorial Temis, Colombia, 1983.

BOVINO, Alberto. Problemas del derecho procesal penal contemporáneo; 1 ed. Editores del Puerto S.R.L.; Argentina, 1998.

BUENO DE CARVALHO, Amilton. De nuevo sobre el interrogatorio del acusado; Revista de la Facultad de Derecho de la Universidad de Granada; España, n. 6, 2003.

BUJOSA, Lorenzo. Algunas cuestiones actuales sobre la prueba testifical; Revista Criminalia; México, n. 1; ene/abr, 2003.

CAFFERATA NORES, José. La prueba en el proceso penal; 6 ed. Editorial Lexis Nexis; Argentina, 2008.

CAFFERATA NORES, José. Proceso penal y derechos humanos; 1 ed. Editores del Puerto S.R.L.; Argentina, 2000.

CÁRDENAS RIOSECO, Raúl. La presunción de inocencia; 2 ed. Editorial Porrua; México, 2006.

CARNELUTTI, Francesco. Derecho procesal penal; 1 ed. Oxford; México, 1999.

CARRILLO PRIETO, Ignacio. Arcana Imperii. Apuntes sobre la tortura. 2 ed. Inacipe. México, 2002.

COLÍN SÁNCHEZ, Guillermo. Derecho mexicano de procedimientos penales; 18 ed. Editorial Porrua; México, 2002. 
COLÍN, Alfredo. Criterios jurisprudenciales en materia de derechos humanos; Revista Lex; México; n. 71; may, 2001.

DÍAZ DE LEÓN, Marco Antonio. Tratado sobre las pruebas penales; 1 ed. Editorial Porrúa; México, 1982.

EDWARS, Carlos. Garantías constitucionales en materia penal; 1 ed. Editorial Astrea; Argentina, 1996.

FERRAJOLI, Luigi. Derecho y razón. Teoría del garantismo penal. 10 ed. Editorial Trotta, Madrid, 2011.

GARCÍA RAMÍREZ, Sergio. El artículo 20 constitucional, en Constitución Política de los Estados Unidos Mexicanos comentada y concordada; 15 ed. Editorial Porrua; México, 2000.

GARCÍA, Fernando. El procedimiento penal en México y Alemania; Revista Criminalia; México; n. 3; set/dic, 2002.

GARCÍA-PABLOS DE MOLINA, Antonio. Tratado de criminología. 4 ed. Tirant lo blanch; Valencia, 2008.

GÓMEZ COLOMER, Juan Luis. El proceso penal alemán; introducción y normas básicas; 1 1a ed. Editorial Bosch; España, 1985.

GONZÁLEZ-SALAS, Raúl. La presunción en la valoración de las pruebas; 1 ed. Inacipe; México, 2003.

GUZMÁN, Guillermo. Fallos históricos de la Suprema Corte de Estados Unidos de América; 1 ed. SCJN, México, 2000.

HASSEMER, Winfried. Persona, mundo y responsabilidad. Bases para una teoría de la imputación en derecho penal. 1 ed. Editorial Temis, Colombia, 1999.

IGARTUA, Juan. El caso Marey; 1 ed. Editorial Trotta; España, 1999

JAÉN VALLEJO, Manuel. Los principios de la prueba en el proceso penal; 1 ed. Universidad Externado de Colombia; Colombia, 2000.

JAEN VALLEJO, Manuel. Tendencias actuales de la jurisprudencia constitucional penal. Las garantías del proceso penal; $1^{a}$ ed. Editorial Dykinson; España, 2002.

KREMER, J. Libro negro del castigo; 1 ed. Editorial Brugera S.A.; Argentina, 1961.

MARCEL, Charles. El laberinto de la investigación criminal; 1 ed. Editorial Porrúa; México, 2003.

MARTÍNEZ GARNELO, Jesús. La investigación ministerial previa; 1 ed. Editorial Porrua; México, 1998.

MIR PUIG, Santiago. Constitución, Derecho penal y Globalización, en Nuevas tendencias en política criminal Una auditoría al Código Penal español de 1995-, 1 ed. Editorial B de F, Argentina, 2006.

MORALES BRAND, José Luis Eloy. El modelo criminológico en el Sistema de Justicia Penal Mexicano.1 ed. Flores Editor y Distribuidor. México, 2010. 
MUÑOZ CONDE, Francisco. Búsqueda de la verdad en el proceso penal; 3 ed. Editorial Hammurabi; Argentina, 2007.

OLIVARES GRULLÓN, Félix. La declaración del imputado ¿Medio de prueba o medio de defensa?; http://www.enel.net/gacetajudicial/1999/66/procesal_penal.htm, consultado en el año 2005

PASTRANA BERDEJO, Juan David. Implementación del proceso penal acusatorio adversarial en Latinoamérica. 1 ed. Flores Editor y Distribuidor, México, 2009.

QUISPE FARFÁN, Fany Soledad. El Derecho a la no incriminación y su aplicación en el Perú. http://sisbib.unmsm.edu.pe/bibvirtualdata/tesis/human/Quispe_F_F/cap4.pdf, consultado en enero de 2015

RODRIGUEZ MANZANERA, Luis. Victimología; 6 ed. Editorial Porrúa; México, 2000.

ROSEN, Tuvia. El polígrafo: mitos y realidades; 1 ed. INACIPE; México, 2002.

ROXIN, Claus. La evolución de la política criminal, el derecho penal y el proceso penal; 1 ed. Editorial Tirant lo Blanch; España; 2000.

Sentencia del Tribunal Constitucional Español, expediente 68/2002, de 21 de marzo de 2002. Recurso de amparo 3147/00. Ponente: Magistrado Dña. Elisa Pérez Vera. http:// criminet.ugr.es/recpc

SOTELO, Luis. La investigación del crimen; 1 re-ed. Editorial Limusa; México, 1978.

TIJERINO, José. Acerca de la declaración del imputado. http://legal56.blogspot.mx/2010/02/acerca-de-ladeclaracion-del-imputado.html 15 de febrero de 2010.

VANDERBOSCH, Charles. Investigación de delitos; 1 re-ed. Editorial Limusa; México, 1976.

ZAMORA GRANT, José. La víctima en el sistema penal mexicano. 1 re-ed. Inacipe. México, 2010.

ZAMORA PIERCE, Jesús. Garantías y proceso penal; 10 ed. Editorial Porrua. México, 2000.

Trabalho enviado em 02 de fevereiro de 2015.

Aceito em 31 de março de 2015. 